\title{
Elementary pre-service teachers working in mathematical borders
}

\author{
Carlos Alfonso López Leiva
}

\begin{abstract}
Using the border metaphor to portray the common separation between school mathematics and students' everyday lives, this manuscript describes the processes that a group of elementary pre-service teachers (PSTs) have experienced to learn about their students and bridge these borders. Content analysis of mathematical activities and PSTs' reflections developed in a mathematics teaching methods course reveals that although they asserted that the process of developing bridges between mathematics and everyday experiences has transformed their self-concept and confidence in mathematics and teaching, they mostly use their own knowledge and experience to develop these tasks rather than from their students'. Possibilities to generate more genuine ethnomathematical approaches are discussed.
\end{abstract}

Keywords: Elementary pre-service teachers. Ethnomathematics. Bridging school mathematics and Everyday Experiences. Mathematization. Culturally Responsive Mathematics Education.

\section{Maestros practicantes de Educación Primaria trabajando en las Matemáticas Fronterizas}

Resumen: Haciendo uso de la metáfora de la frontera para indicar la separación frecuentemente existe entre las matemáticas de se enseña en la escuela y las vidas de los estudiantes, este manuscrito describe los procesos que un grupo de maestros practicantes de educación primaria (MPEP) vivieron para aprender acerca de sus estudiantes y unificar estas fronteras. El análisis de contenido de las actividades matemáticas y las reflexiones de los MPEP desarrollaron en un curso de métodos de enseñanza de las matemáticas reveló que aunque los MPEP afirmaron que el proceso de crear puentes entre las matemáticas y experiencias cotidianas transformaron su auto-concepto y confianza in matemáticas y la enseñanza, ellos mayormente utilizaron su propio conocimiento y experiencia para desarrollar estas actividades, más que las de sus estudiantes. Posibilidades para generar acercamientos etnomatemáticos más genuinos son discutidos.

Palabras clave: Maestros practicantes de Educación Primaria. Etnomatemática. Puentes entre las

Carlos Alfonso López Leiva Doctor in Philosophy in Curriculum and Instruction with specialization in Bilingual Mathematics Education by The University of Illinois at Chicago (UIC). Associate Professor in the Department of Literacy, Language and Sociocultural Studies in the Program of TESOL and Bilingual Education at the University of New Mexico (UNM) New Mexico, United States of America.

(iD) https://orcid.org/0000-0002-9010-6823 $\triangle$ callopez@unm.edu

Received in 02/09/2019 Accepted in 07/12/2019 Published in 04/03/2020 Matemáticas y las experiencias cotidianas. Matematización. Educación Matemática culturalmente responsiva.

\section{Professores da Educação Primária trabalhando em fronteiras Matemáticas}

Resumo: Usando a metáfora da fronteira para retratar a separação que geralmente existe entre a matemática ensinada na escola e a vida dos alunos, este artigo descreve os processos que um grupo de professores da Educação Primária em formação (PFEB) experimentou para aprender sobre os seus alunos e unificar esses limites. A análise do conteúdo das atividades matemáticas e as reflexões que os PFEB desenvolveram num curso de métodos de ensino de Matemática revelaram que, embora eles afirmassem que o processo de criação de pontes entre Matemática e as experiências quotidianas transformou o seu autoconceito e confiança na Matemática e no ensino, eles usaram principalmente os seus próprios conhecimentos e experiências para desenvolver essas atividades, mais do que as de seus alunos. Possibilidades para gerar abordagens etnomatemáticas mais genuínas são discutidas.

Palavras-chave: Professores da Educação Básica em formação. Etnomatemática. Pontes entre Matemática e experiências quotidianas. Matematização. Educação Matemática culturalmente responsável. 


\section{Introduction}

Acknowledging children's linguistic, intellectual, cultural and social resources is deemed as central in the process of developing an educational environment that is inclusive of students' experiences at home and in their communities (MOLL, 1992). In mathematics education, besides considering children's funds of knowledge, it is important to include open tasks offering students multiple ways of engaging in mathematics, as well as to make sense of these tasks by engaging in mathematical meaning-making activity (LESH et al., 2000; NGACBP, 2010). Integrating these perspectives in the preparation of pre-service teachers represents both a great potential and a challenge.

This paper describes Ethnomathematics as an important approach in teacher preparation to support this link, since Ethnomathematics represents a "way that members of various cultural groups mathematize their own reality because it examines how both mathematical ideas and practices are processed and used in daily activities" (D'AMBROSIO \& ROSA, 2017, p. 288). More specifically, this manuscript describes the challenges and affordances that a group of pre-service teachers (PSTs), participating in a mathematics teaching methods course, faced creating and developing tasks that were sensitive to their students' culture, language, interests and experiences. The analysis of PSTs' work on ethnomathematical approaches provides an insight of how PSTs' are bridging children's funds of knowledge and mathematics during their design of ethnomathematical activities.

Ethnomathematics is a term introduced by Ubiratan D'Ambrosio (1991) to describe the techniques used to explain, understand and cope with reality in order to survive across diverse communities. Ethno relates to the members of distinct groups identified by cultural traditions, codes, symbols, myths and specific ways of reasoning and inferring (D'AMBROSIO, 1985). As Ethnomathematics centers on the mathematizing of frequent activities in specific communities (D'AMBROSIO \& ROSA, 2017), such stance highlights mathematics as a cultural practice existent in human activity and challenges the perspectives that present mathematics mainly as a Western — Roman, Greek — knowledge, commonly taught at school.

An ethnomathematical approach helps us understand mathematics from a wider perspective than traditional school mathematics, seeing mathematics as a human act. As a result, Ethnomathematics can help us renovate the way we teach mathematics (LANGE, 1996; D'AMBROSIO \& ROSA, 2017). In mathematics teaching and learning, Ethnomathematics helps us: expand, affirm and redistribute mathematical authorship and empowerment; draw from and expand resources to teach and learn mathematics; recognize and challenge spaces of marginality 
of knowledges of many communities; and strengthen the relationship between learners and mathematics (AGUIRRE, INGRAM-MAYFIELD \& MARTIN, 2013; KOKKA, 2015).

Such approach should "perpetuate and foster — to sustain — linguistic, literate and cultural pluralism that are part of schools" (PARIS, 2012, p. 93). Thus, when students and teachers use their real world as a starting point for conceptual development, mathematics teaching and learning become more complex (LANGE, 1996) as they also become doers of mathematics (NCTM, 2000) by engaging in problem solving, multi-modal representations and communication to develop mathematical meaning making and mathematize through their own perspectives (NGACBP, 2010; FREUDENTHAL, 1973).

\section{Context of the Study}

This study includes the work with PSTs in a mathematics teaching methods course within a teacher-preparation initiative named TECLA (Teacher Education Collaborative in Language Diversity and Arts Integration) project. TECLA project is the result of the collaboration of seven professors in a United States (US) southwestern university across two different colleges and three different departments. Professors worked with the group of PSTs at different times along the three semesters that PSTs spent in TECLA as part of their Elementary Education undergraduate degree program.

The project focuses on a collaboration process among the professors that designed the program structure for the PSTs by integrating the content of their courses and field experiences. This collaboration is also extended to the relationship developed between the Cooperating Teachers at the hosting school and the PSTs planning and co-teaching since the first day of the PSTs' field work. There were also an Arts and Curriculum teacher and a graduate student, who collaborated with the Cooperating Teachers, PSTs and professors, bridging together the work of everyone in the project and guaranteeing the extended integration of all activities in the project. Although the project's general approach relates to an Arts-Integration (FALTIS, 2019; MARSHALL \& DONAHUE, 2014), at the center of there is a social-justice goal that focuses on the linguistic and cultural diversity of the students' background at the hosting school.

The project hosted at an Elementary School, La Montañita, which is a community school that has Spanish-English, Navajo-English bilingual programs and welcomes a great diverse student population. According to the school district data, this school includes students who are $86 \%$ Hispanic, 7\% American Indian, 3.5\% African American, 2.6\% White and 0.8\% Asian. Additionally, 
a great influx of refugees and immigrants and also languages characterize students' population at this school. The PSTs' program in TECLA project is described in Table 1 below.

Table 1: Timeline of PSTs' expected work and activities in TECLA

TECLA ACTIVITIES

Field work
Coursework
Integrational thematic
emphasis in coursework
and field experiences

Arts Events $1^{\text {ST }}$ SEMESTER

$$
\begin{aligned}
& 2 \text { days weekly } \\
& \text { Math Methods } \\
& \text { Literacy Met. I } \\
& \text { Literacy Met. II } \\
& \text { Seminar I } \\
& \text { TESOL/BIL ED } \\
& \text { courses }
\end{aligned}
$$

$\begin{array}{ll}\text { Funds of Knowledge } & \begin{array}{l}\text { Social Issues, Critical } \\ \text { Literacy and Arts } \\ \text { Integration }\end{array}\end{array}$

$2^{\text {ND }}$ SEMESTER

3 days weekly

Social Studies Met.

Science Met.

Literacy Met. III

Seminar II

TESOL/BIL ED courses
3RD SEMESTER

All weekdays

Seminar III

TESOL/BIL ED courses

Literature, Culture and Arts Integration

Classroom Museums

Bringing Books to life

Literacy week

Source: Elaborated by the Author

As shown in Table 1, PSTs in the Mathematics Methods course focused on "Funds of Knowledge" as a generative and integrative topic across coursework and field experiences. The group of PSTs described in this manuscript includes: 4 male (1 Hispanic and 3 White) and 18 female (10 Hispanic and 8 White) college students in the Elementary Education Program. Only 6 PSTs were bilingual (Spanish and English). All PSTs were their first semester of the program and fieldwork, which includes two full days at school. PSTs taught in K-5 grades: 5 in Kindergarten, 4 in first grade, 6 in third grade, 4 in fourth grade and 3 in fifth grade. Funds of Knowledge served as a framework/theme integrated across the methods courses during the first semesters; this thematic emphasis varied in the next two semesters. This study reports PSTs' work only during the first semester.

Consequently, language and culture were explored along the entire mathematics methods course, though this course curricular structure addressed aspects related to: mathematics reform such as mathematics processes and teaching standards (NCTM, 2000), mathematical practices and emphasis on problem solving (NGACPB, 2010; VAN DE WALLE, KARP \& BAY-WILLIAMS, 2013), Cognitively Guided Instruction, valuing and building on children's thinking and reasoning (CARPENTER et al., 2014; FOSNOT \& DOLK, 2001), facilitation of mathematics instructional conversations (CHAPIN, O'CONNOR \& ANDERSON, 2013; PARRISH, 2014), promotion and 
development of mathematical discourse (MOSCHKOVICH, 2002), collaborative learning (LOTAN, 2003), planning and selecting worthwhile mathematical tasks (STEIN et al., 2000).

This curricular structure was aligned with the generative topic supported by TECLA and the course content integrated language and culture perspectives as follows. In the first module: perspectives of English learners (ELs) (RAMÍREZ \& CELEDÓN-PATTICHIS, 2012), different mathematics algorithms in Latin America (PERKINS \& FLORES, 2002), suggestions for working with ELs (BRESSER, 2003; GARRISON \& MORA, 1999; MOSCHKOVICH, 2013), applications of mathematics to real-life events and community (LO CICERO, FUSON \& ALLEXSAHT-SNIDER, 1999; SIMIC-MULLER, TURNER \& VARLEY, 2009), students' mathematical identities (BOALER \& GREENO, 2000), walk through the community and charlas (forums) with mothers of students at La Montañita. Then, two consecutive modules address the mathematical educational concepts described above, always focusing on students and their community.

Consequently, students' funds of knowledge in mathematics were addressed by PSTs through reading, thinking about, observing and reflecting on the community. PSTs often need to learn about both the mathematics reform ideas and funds of knowledge. The process of bridging these topics seems overwhelming, so the class conversations and reflections took more time than expected. As an instructor, I worry about integrating students' funds of knowledge in mathematics teaching (GONZÁLEZ et al., 2001), ethnomathematics, through the development of community mathematization projects, and the "mathematical" teaching practices described in Principles to Actions' (2014), mainly problem solving and their relevance in nurturing children's reasoning and understanding.

Nevertheless, once PSTs engaged with these integrated perspectives, they started making clear connections across course modules and in their teaching practices construction they collaborated with each other and encouraged peers to incorporate children's thinking, language, funds of knowledge, self-perception in mathematics and problem-solving strategies. As a result, PSTs helped me to realize that in a mathematics-methods course the focus is on children - who they are, where they come from, what they care about, what they know, what is going on around them. This is the essential foundation of all academic and pedagogical content knowledge for teaching mathematics.

\section{Mathematics Teaching, Funds of Knowledge, and PSTs' Preparation}

Investigations about students' funds of knowledge highlight the relevance of an education 
that actively includes students' community, backgrounds and language in the teaching and learning of school contents and languages. Funds of knowledge (MOLL \& GREENBERG, 1990) include "the knowledge base that underlies the productive and exchange activities of households" (MOLL \& GONZALEZ, 2004, p. 700). Funds of knowledge are not possessions of people in the family; instead they are "part of what people do in activities" (MOLL, 1992, p. 222); they refer "to the content and the social relationships that facilitate the exchange" (p. 231). Such knowledge and social relationships are flexible and adaptive, so they can be mobilized across contexts and activities, including mathematics learning and teaching (GONZÁLEZ et al. 2001; MOLL \& GREENBERG, 1990; MOLL, 1992).

Students' funds of knowledge are linked to pedagogies valuing diverse students' life experiences and communities which were deemed from deficit views. Culturally Relevant Pedagogy (CRP) is defined "as using the cultural knowledge, prior experiences, frames of reference and performance styles of ethnically diverse students to make learning encounters more relevant and effective for them" (GAY, 2000, p. 29). CRP encompasses a process through which all students have the opportunity to experience academic success, develop and/or maintain cultural competence and develop a critical consciousness through which the status quo of the current social order is challenged (LADSON-BILLINGS, 1995). CRP perspectives have evolved into complex constructs that acknowledge societal power structures, so that the emphasis is placed on an integrated and sustainable development of cultural and academic competences of students:

The term culturally sustaining requires that our pedagogies be more than responsive of or relevant to the cultural experiences and practices of young people - it requires that they support young people in sustaining the cultural and linguistic competence of their communities while simultaneously offering access to dominant cultural competence (PARIS, 2012, p. 95).

Several approaches in mathematics education specifically addressing the link between minoritized and dominant cultural competences have emerged. For example, Gonzalez et al. (2001) describe a 'Zone of Mathematical Practice' as an interactional space where the following processes take place: (a) the development of inter-subjectivity, sense making in joint activities with others, (b) equalized social interaction, equal validation of participants, (c) a kind of mathematics that is playful, accessible and 'natural', and (d) funds of knowledge are transformed into meaningful activity in mathematics. Many of these approaches have highlighted the role of parents and community members in mathematics education of children from cultural and linguistical diverse communities (CIVIL \& BERNIER, 2009; CIVIL, BRATTON \& QUINTOS, 2005; CIVIL \& QUINTOS, 2006). 
Aguirre (2012) suggests a Culturally Responsive Mathematics Teaching (CRMT) approach with two main goals: (a) students' development of mathematics thinking and (b) equity in mathematics classroom. As so, for the implementation of a CRMT approach teachers need to develop specific pedagogical knowledge, dispositions and practices that mobilize students' funds of knowledge, nurture their mathematical thinking and promote social justice in mathematics education.

In consequence, this study's theoretical framework is founded on the explicit acknowledgment of the participants' linguistic, intellectual, cultural and social knowledge in mathematics education. For example, Moschkovich (1999) recommends that when working with Latinx ${ }^{1}$ students, mathematics teachers should: (a) honor the diversity of Latinx students' experiences, (b) know the students, (c) avoid deficit models, and (d) provide opportunities for mathematical discussions. Regarding the preparation of PSTs, it means that they need to engage in an explicit work and understanding on how to bridge students' funds of knowledge and mathematics. This means that PSTs need to work at the borderlands or liminal spaces of thinking about both their students and mathematics, linkage which is mediated by PSTs themselves.

Thus, who PSTs are is a crucial element to this linking process. PSTs need to work as Nepantler@s. Nepantler@s, according to Anzaldúa, travel in many disciplines to "invent holistic, relational theories and tactics enabling them to reconceive or in other ways transform the various worlds in which they exist" (KEATING, 2006, p. 9) to support bridges between students' lives and school. Only a careful ethnographic analysis of the transmission of these resources at home and their application into school instruction will support a convincing demonstration of children's knowledge in their academic performance (MOLL, 1992). Moreover, besides PSTs' inclusion of children's funds of knowledge, in mathematics education designing open tasks is also important since they offer students a context to engage with mathematics, to make sense of it and engage in mathematical activity (LESH et al., 2000; NCTM, 2000; NGACPB, 2010).

In my opinion, it is through the inclusion of the learner's prior perspectives that school mathematics becomes integrated with the learner's knowledge basis. In mathematics education several approaches have targeted the link between school and community mathematics; for example, Ethnomathematics (D'AMBROSSIO, 1991), Realistic Mathematics Education (RME) approach (WEBB, VAN DER KOOIJ \& GEIST, 2011) and mathematization processes (GRAVEMEIJER, 1997). In RME, "students connect prior knowledge to new mathematical

\footnotetext{
1 I use the term Latinx acknowledging gender diversity and fluidity rather than a dichotomized view.
} 
representations, concepts and skills.

As a result, a more robust way of knowing and doing mathematics is constructed from the student's perspective" (WEBB, VAN DER KOOIJ \& GEIST, 2011, p. 48). The realistic portion does not necessarily imply connections "with real world contexts, but it is related to the emphasis that RME puts on offering students problem situations which are imaginable" (WEBB, VAN DER KOOIJ \& GEIST, 2011, p. 48) or realistic in the view of the students. When students engage in mathematical tasks that blur borders and become relevant to students and their social interactions, then tasks promote the emergence of a "zone of mathematical practice" (GONZÁLEZ et al., 2001).

Holistically, the conceptual framework in this study centers on how PSTs mathematize their own reality and their students' reality in order to promote mathematical tasks that overcome the borders that school mathematics often places between students' daily life and mathematical activities and practices (D'AMBROSIO \& ROSA, 2017).

Some works in mathematics education have explored how PSTs have grappled in linking mathematics and the community. For example, Drake and Norton-Meier (2007) promoted PSTs' awareness of family and community resources by integrating mathematics and literacy and by linking family and community funds of knowledge with school-based content in the methods course. They describe how 51 PSTs learned, experienced and enacted these overlaps by interacting with parents during the planning and lessons implementation.

Authors found that for PSTs there are evident links between mathematics and literacy but the "boundaries between funds of knowledge and academic content proved to be quite rigid and very difficult to cross in the context of a one-semester course" (D'AMBROSIO \& ROSA, 2017, p. 188). Nonetheless, the authors describe that the overlap of contexts created potential connections across contexts for PSTs to promote better connections between the community and school mathematics.

Also, Aguirre, Zavala and Katanyoutanant (2012) described how a mathematics methods course emphasizes the connections among mathematics, children's mathematical thinking, children's funds of knowledge and mathematics for social justice. Through mixed methods the authors found that PSTs has given more explicit attention to issues associated with children's mathematical thinking and their academic language by integrating cultural funds of knowledge, than issues related to mathematics for social justice. Nevertheless, those issues were possibly linked to pedagogical rather than ideological challenges.

Finally, Aguirre et al. (2013) describe how 70 PSTs from three universities visited 
community settings and developed problem-solving mathematics lessons that linked mathematical practices to the community settings. In this analysis, the authors identified three levels of these connections (i.e., emergent, transitional and meaningful). These connections showed different levels of consistency in addressing both children's mathematical thinking and funds of knowledge in their teaching.

\section{Methods and Data Sources}

Content analysis process is a "technique for making inferences by objectively and systematically identifying specified characteristics of messages" (HOLSTI, 1969, p. 14). In order to explore the processes of integrating children's funds of knowledge with school mathematics, as well as how the 22 PSTs understood these processes as part of their mathematics teaching practices with bilingual and bicultural students, I used content analysis.

I qualitatively analyzed the first-semester PSTs' assignments, such as module reflections, the community-based lesson (CBL) paper and their journal reflections, taken during course classes and fieldwork experiences, as well as the instructors' field notes. The CBL paper was developed by PSTs through interviews with their students and observations of them during class and breaks. Some of them also consulted the cooperating teachers.

The initial themes of the analytical process were related to the content either of the task/problem that PSTs developed or their reflections linking students' funds of knowledge with mathematics teaching and learning. A second level coding yielded overarching themes that are described in this paper and which are illustrated through examples that come from PSTs' work. While PSTs' gender did not represent a major variable for these patterns, PSTs' cultural and linguistic backgrounds had a more significant but still not consistent role across cases.

\section{Results}

Three themes permeated PSTs' transformative knowledge and actions in mathematics education: (a) finding links between students' funds of knowledge and mathematics- PSTs' investigations about their students' funds of knowledge revealed various potentially-rich contexts and practices that could support links between school and community mathematics; (b) developing these links based on PSTs' personal experiences-while some PSTs acknowledged the identified contexts or practices related to the students' funds of knowledge or community wealth, PSTs used 
their ideas and experiences to present these links; and (c) developing these links by mathematizing student-centered experiences-PSTs used student-relevant potentially rich-mathematical contexts as sources for students' mathematical investigations and problem solving, The inclusion of students' experiences linked more directly students' personal identities and funds of knowledge and to seeing themselves as doers of mathematics. Each of these themes is described below with examples of PSTs' work.

\subsection{Finding Links Between Students' Funds of Knowledge and Mathematics}

Through interviews and classroom activities, PSTs' developed an inquiry about their students' funds of knowledge, which served as a foundation to develop mathematical tasks. Table 2 presents a list of twelve activities that PSTs identified as potential sources to establish connections between students' funds of knowledge and mathematics. This list describes human activities that resemble Bishop's (1988) list of mathematical activities across cultures, which include: Counting, Locating, Measuring, Designing, Playing and Explaining. For example, cooking includes measuring, sports can include several of these activities, using money includes counting, etc. The activities that children reported engaging in at home include thinking and actions that while not explicitly and deliberately linked to school mathematics, they are still mathematical.

Table 2: Activities PSTs' Found to Link Mathematics and Funds of Knowledge

\begin{tabular}{lc}
\hline \multicolumn{1}{c}{ Activities } & $\begin{array}{c}\text { Frequency among } \\
\text { Interviewed Students }\end{array}$ \\
\hline Cooking & $50 \%$ \\
\hline Playing and Designing Sports & $45 \%$ \\
\hline Watching TV & $25 \%$ \\
\hline Using Money & $20 \%$ \\
\hline Taking care of Animals & $15 \%$ \\
\hline Planning Parties & $15 \%$ \\
\hline Shopping & $15 \%$ \\
\hline Understanding of Science-fiction Movies or Stories & $15 \%$ \\
\hline Playing Board Games & $15 \%$ \\
\hline Music & $10 \%$ \\
\hline
\end{tabular}




\begin{tabular}{lc}
\hline Designing Seamstress Work & $10 \%$ \\
\hline Noticing Everyday geometry & $10 \%$ \\
\hline
\end{tabular}

Source: Survey Data

Learning about students' funds of knowledge started PSTs' borderlands' journey to start developing links between school and community mathematics. Thus, PSTs were challenged to design mathematical tasks that could mobilize these community activities and knowledges into school mathematics concepts. Among the repertoire of funds of knowledge that PSTs recognized in their students related to ideas described in the course readings. For example, the fact that algorithms and the writing of numerical symbols vary across cultures and countries. Marta, in her reflection of module 1, made connections to the course reading of Perkins \& Flores (2002), describing algorithms in Latin America:

Marta: This was very surprising to me, but I was able to see firsthand some of these important differences. A girl in my assigned classroom is new to the United States from Ecuador, and while I was helping her with math I wrote a 7 (uncrossed) and she read it as a one, I am still getting used to the way she writes her 1s, which, to me, look sometimes like 7s. Respect means that teachers will not negatively view the knowledge (or funds of knowledge) that students bring to the classroom, but will instead use them to aid the education process. Respect also means eliminating "the notion that methods used in schools in the United States are inherently better" (Perkins and Flores, p. 124).

PSTs' reflections on students' funds of knowledge were extended, not only through readings, but also through their own experiences with their students. These reflections included also the process of devising and designing responsive mathematical tasks. Andrea reflected on how she envisioned the possible mobilization of students' funds of knowledge in mathematics by addressing beyond the content of her students' funds of knowledge:

Andrea: The perfect way to motivate students and create a complexity of literature is by learning how to mobilize funds of knowledge in a classroom. The way I plan to mobilize funds of knowledge in my class is by pulling each student own experiences to help them like math. For example, if a student comes from a family where they own a business then this child must know some type of math. I can relate back to him and say for example, "Well Johnny you know how your dad owns a store, how does he add up all the money in the cash register? Maybe you can help us teach addition today." Another great idea would be to invite Johnny's dad into the class as a guest speaker so that he can briefly explain how he conducts such task. By creating social interactions, funds of knowledge can easily be mobilized to benefit our students.

Andrea's argument supports the notion that funds of knowledge are not simply related to "what" or the content of an activity in the life of a student, but also to the kind of social relations that 
both generated and mobilize those ideas. In this way, empty uses of "whats" would be insufficient if they are not supported by social interactions that nurture them to get into the new context of learning school mathematics.

Although PSTs developed stances about how they would address the bridging of student experiences and mathematics, PSTs' prior experiences in mathematics also affected how they conceptualized a mathematical task. Then, the levels of risks they took to mathematize a potentially-rich-mathematical activity related to students' funds of knowledge was constrained by how PSTs self-received in relation to mathematics. These relations were informed by their experiences with school mathematics.

Thus, I find it crucial to consider PSTs' emotional landscape as a baseline to engage in the design of mathematical tasks. As a result, PSTs' lived experiences in school mathematics had a major influence in their level of freedom to go beyond traditional school mathematics. $90 \%$ of PSTs argued to have experienced a memory-based mathematics instruction and not being able to develop positive identities as doers of mathematics. Their idea about what mathematics teaching and learning was partly renovated as they took mathematics content courses in their Elementary Education Program. Viviana's excerpt describes her experience as a student:

\footnotetext{
Viviana: I struggled a lot. Information just did not stick. Math was the only subject that I did not excel in, which made for a very sad, young little girl. I felt unintelligent and that my input, opinion or thoughts were not necessary or needed. Instead of being the student who felt confident to raise her hand and answer questions, be the Math group leader, or the student who was happy to see her test scores; I was the one who sat passively year after year, dreading Math class, being so nervous the night before a test that I could not sleep.
}

Experiences such as Viviana's were not uncommon among PSTs. These situations highlight that at the borderland of linking school and community mathematics, PSTs grapple with more than just establishing a link. They need to face who they think they are in relation to mathematics. Furthermore, as these borderlands also include the linking of cultural practices, the connection that PSTs noted between their experiences and their students' was affected by their perceived connections between self and the students' community. It is further described next.

\subsection{Developing Links between School and Community Mathematics Based on PSTs' Experiences}

As PSTs developed of mathematical tasks related to what they had learned about their 
students' funds of knowledge, these tasks were not always directly linked to the students' but rather PSTs' experiences. For example, some PSTs identified music and sports as important activities related to their students' funds of knowledge; however, during the development of mathematical tasks some PSTs drew from their own funds of knowledge and experiences instead of from their students'. The work of Daniel and Diane represent this situation.

They made use of their prior experiences and knowledge to link what they found about their students' funds of knowledge. Daniel - a PST who enjoys music very much, after realizing that the students he interviewed enjoy music also - developed a task linking music and mathematics. He worked in Kindergarten and needed to teach about patterns. Daniel linked the concept of patterns with music through a task of using pattern blocks and linking each shape to an action or sound, so that the shapes could be sequenced in different patterns to create patterns of shapes and rhythms or 'music'.

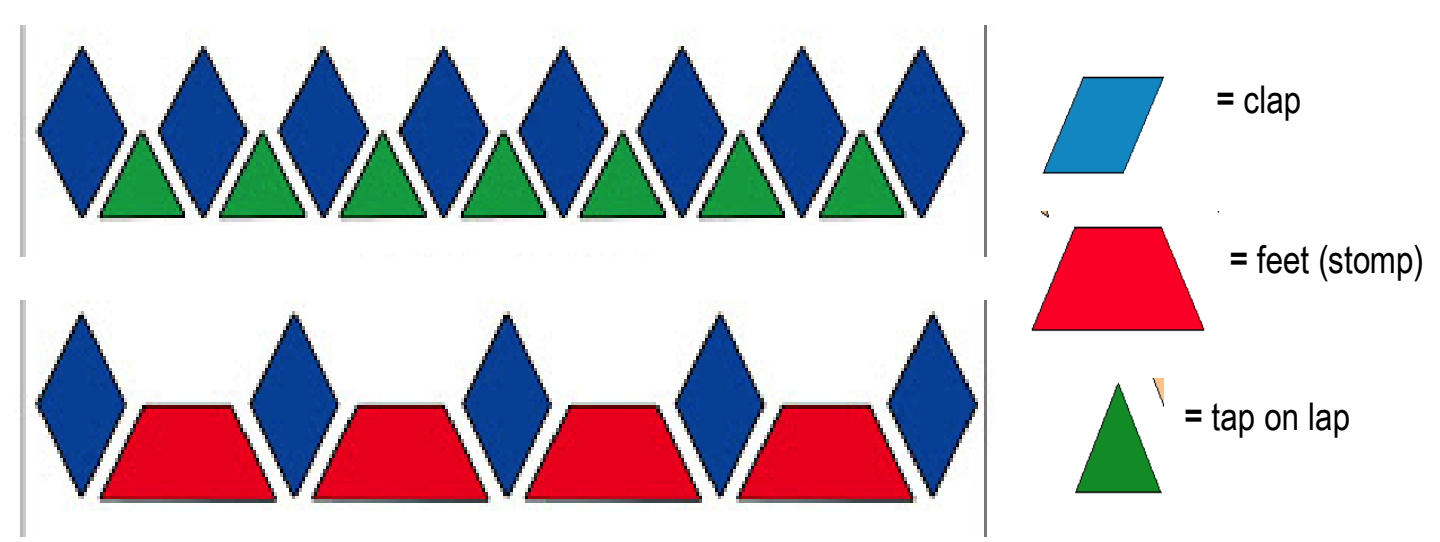

Figure 1: Pattern blocks used to explore mathematical and rhythmic patterns

Daniel: The activity will have students to understand what a sequence is. For example, I will say clap, clap, legs, legs, feet and feet. I will repeat this sound sequence twice and students will try to remember this pattern of counting. Another example could be feet, clap, clap and feet, also repeated twice. This task allows students to learn the importance of counting in the rhythm of songs. Notice that if one student forgets to count the sequence correctly, he will lose the rhythm of the song. However, it doesn't mean that he can't figure out the sequence in the right order after he got lost.

When Daniel implemented this task, he modeled to students how to create rhythms. Students were able to decide the arrangement of the shapes and what they represented. In this way, students "wrote" different patterns and rhythms. This task promoted student participation and motivation in pre-algebraic thinking. While this task related to music, the task itself did not directly align to students' experiences with mathematics, but to Daniel's adaptation of musical rhythm represented through shapes.

In the case of Diane, she found out that her students like soccer, used the idea of soccer 
not to create a soccer embedded mathematical task. Instead she developed a task/game in which students imagined that they were playing soccer and annotated a goal by responding to a question related to a mathematical operation, like "what is 5 times 5 ?". Another PST also used a golf game board in which students could move along the board by responding to subtraction operations. In the two cases students did not engage in the games as expected by PSTs. It is not sure whether students viewed the tasks as related to the sports they like.

Some PSTs could not find ways to link more directly their students' funds of knowledge with mathematics; and instead they developed mathematical tasks that were superficially related to funds of knowledge and required low levels of cognitive mathematical reasoning. This lack of social and mathematical authenticity relates to the fact that the activity of playing soccer or golf is not the same as playing a board game that relates to golf or soccer; even the mathematics involved in soccer does not relate to answering to basic facts fluently. A board game is another activity that might not always be significant to the students. Funds of knowledge are to be transformed into meaningful activity in mathematics, these include activities people do in a community and to the content and the social relationships in those activities (GONZALEZ et al., 2001; MOLL, 1992).

It is not only to be responsive or relevant to a cultural content, experiences or practices of a community, a culturally sustaining approach requires to sustain the cultural and linguistic competence of the communities while simultaneously offering access to academic competence (PARIS, 2012). This situation makes one wonder about what needs to happen so that PSTs find relevance between their students' funds of knowledge and their own? How does this connection facilitate the process of establishing these nuanced links? What is the actual issue? Drake and Norton-Meier (2007) have found rigid boundaries between funds of knowledge and academic content. Daniel was able to find links between music and mathematics due to his familiarity with both, but he was not as successful in bridging this familiarity with his students'.

Diana on the other hand was not familiar with soccer but instead she was more familiar with game boards, which is what she used. She also could not find a direct mathematical connection to the game, so she resourced on basic mathematical facts. These ideas speak to situations when adaptations of mathematical problems to make them culturally responsive by simply changing some names or words in the word problem. This adaptation focuses on what without acknowledging the social dimension of those activities that characterize the meaningfulness of the activity to the community.

Further, familiarity with mathematical content and what helps students learn mathematics are important knowledges that can better support PSTs' development of mathematical tasks. Diana 
reflected on these points in her following assignment as she focused more on the mathematics and less on the cultural responsiveness of a mathematical task. It takes explicit reflection and experience with who students are and their ways of learning. More studies exploring bridges between PSTs' funds of knowledge and their students', especially how PSTs cope with these differences as well as the quality of connections established between the mathematical task and the activity related to the students' funds of knowledge are needed.

\section{Developing Links between School and Community Mathematics Based on Students' Experiences}

The relevance of a Culturally Responsive Mathematics Teaching (CRMT), which is based on the need of a genuine exploration of students' funds of knowledge; especially of those from minoritized groups, was evident to all PSTs. This relevance had different connotations. Some PSTs have had personal experiences that informed them directly about the importance of addressing student's diversity in the teaching of mathematics. PSTs wanted to make a difference and effect changes in education, so that education would be more inclusive of students' experiences, cultures and languages. Laura's comment extends this argument beyond mathematics education:

Laura: This is something I always struggled with in school because it felt like in every class the material always focused on my white counterparts' lives and it was just something that made me not interested in school. However, one thing I might add and caution future teachers, even myself, is to not try and make the problem without finding out about students' lives, meaning don't just add a problem about making tamales because you have a Latino student and assume he makes them on his spare time.

To Laura, knowing students is of great importance to guide teachers' teaching and curricular adaptations away from essentialist cultural perspectives based on their students' backgrounds. Instead, Laura called for a more authentic process of getting to know her students. Laura's insights derived from her own experiences as a Latina student. Her familiarity with this issue granted her with awareness about important aspects of being a teacher with this student population.

Such stance has been documented with Chicana teachers whose identities and previous experiences contribute to how they define their professional role in relation to students from a similar cultural minority background as well as their awareness of the challenges that minoritized students face (GALINDO, 1996). As a result, Laura's adaptation of mathematical tasks, drew from non-essentialistic students' funds of knowledge of Latinx students. She worked with a group of girls 
mathematizing formations and positions for a cheerleader presentation. Students used mathematical activities such as measuring time and designing symmetric formations

Brisa's teaching experience speaks to a similar situation. Nevertheless, as she was working on perimeter and diameter of geometric shapes, she wanted her students to apply and reinforce such concepts and ideas. Looking for challenging experiences for $5^{\text {th }}$ graders and having mathematical explorations outside of the classroom, she noted maple trees around the school playground. Furthermore, aware of students' funds of knowledge reports on exploring geometry in nature and that students needed to study plants in Science. She developed a task - 'how much a maple leaf measures?' - , in which students had to find the area and perimeter of a leaf.

To solve the task, students had to use unconventional unit measures. When, Brisa asked how they would measure the leaf's perimeter and area, students resourced to using the squares on a sheet of grid paper as unit of measurement. Arguing that the edge or margin of the leaf is the perimeter, and the area is the lamina or blade of the leaf. Figure 2 below presents an example of students' work on this task. Note that students differentiated between the two-dimensional aspect of the measuring of area as it covers entire squares, while the perimeter related only to the length of a side of the square.

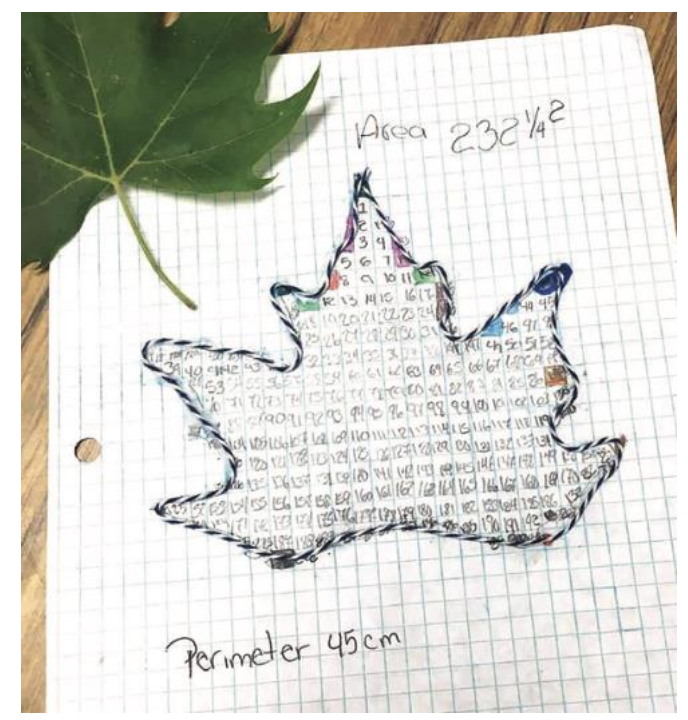

Figure 2: Brisa's task, finding the area and perimeter of a maple leaf

In a personal reflection about teaching field experiences, Brisa mentioned: "I enjoyed my math methods class because it was at La Montañita. It gave me a real feeling of being in a classroom with kids that put myself out of my comfort zone". In Brisa's reflection, we observe how PSTs' self-concept in mathematics serves as a starting platform in the borderline to start developing sensitive links between the students' ideas and mathematics. Further, as Brisa took risks and engaged in developing mathematical experiences more tangible and meaningful for her students, 
students participated more enthusiastically and genuinely to the point that they learned and showed their learning and desire in completing the task in the best way possible. In turn, Brisa's confidence in doing and teaching mathematics also increased. Thus, I think that as we attempt to blur boundaries between school mathematics and our students, we also blur those boundaries for ourselves as mathematics teachers. Both students and Brisa remarked feeling more competent in mathematics by engaging in such application of mathematics.

Another daily activity that was very common among students from the school was the watching of TV programs. However, the pool of TV programs that they had watched was very diverse. For example, Surama found that students from Mexican background in her class enjoyed watching the program "El Chavo del 8". Consequently, Surama decided to use this context to design a mathematics problem. Knowing that El Chavo is always hungry and that divind chocolate bars can lead into thinking about fraction, she had students think of the characters wanting to share a chocolate bar, so students came up with the following problem:

"El Chavo, La Chilindrina and Quico, were playing with Quico's ball when La Popis arrives with a chocolate bar. El Chavo's eyes almost pop out with excitement and he sticks out his tongue. Everyone crowds around La Popis and begs to have a piece. She says she will be happy to share it, but she wants to make sure everyone gets an equal amount. They start to share the chocolate bar, but they get confused and start fighting. Luckily, El Profesor Jirafales notices them fighting and offers to help.

El Profesor Jirafales sees this:

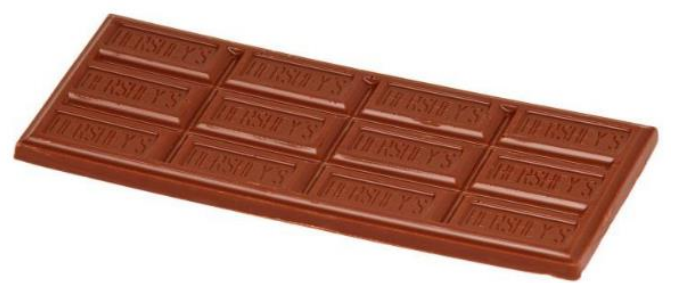

El Profesor Jirafales knows how he can divide the chocolate. Do you?

First, solve the problem in a way that makes sense to you. You can use pictures, draw on the chocolate, or use numbers to help you solve the problem.

Next, explain how you can use fractions to solve this problem.

Now that you know how to divide the chocolate among four people, I will give each group."

This problem presents multiple entry points to solve it, but it also requires a high level of cognitive reasoning because students are engaged in "doing mathematics" (STEIN et al., 2000). Students mathematized the division of the chocolate bar by either dividing it into fractions or using the already embedded structure of this composite unit. Although the mathematical concepts embedded in this problem were rich, the content and social interactions of the problem also showed the type of jokes and interactions that exist in El Chavo program.

This speaks that the content of the program was left and used as it is, but it served as a context to creating a problematic situation that resembles common situations in the practice or TV 
program that students are familiar with. Further, the use the characters' gender in Spanish, as in the case of El Profesor Jirafales and La Popis, was the result of students knowing and liking the show. Surama herself was familiar with both the TV program and fractions. As a result, we note how PSTs make use of their own funds of knowledge to design mathematical tasks that were culturally responsive to their students' funds of knowledge.

I learned that while PSTs from similar linguistic and cultural backgrounds as their students' had a critical awareness, PSTs from mainstream, White backgrounds, also developed responsiveness (LADSON-BILLINGS, 1999) by intentionally learning about these students and developing a genuine commitment to implementing teaching practices that supported who the students are. Most of PSTs successfully integrated student's funds of knowledge and mathematical concepts such as basic operations, fractions, measurement, geometry, money value and exchange, number sense, modeling, patterns, estimation and decimals. However, this integration also showed the establishment of links with PSTs' funds of knowledge. For example, Hispanic PSTs had similar experiences to those from Hispanic students they interviewed.

\section{Concluding Remarks}

"Successful cases of integration are characterized by 'transformative practice zones' that 'provide spaces to share and listen to others' ideas, visions and commitments, and to build relationship in collaboration across disciplines" (BRESLER, 2003, p. 24). I learned through the PSTs I worked with that when we take risks working to blur the borders between mathematics and students' experiences, we also blur those borders for and within ourselves. Therefore, we are contributing to a renovation of how we see ourselves as mathematics' doers and especially as mathematics' teachers. A stronger and closer relationship with our students and mathematics is revealed in our eyes and in our heart, just as Brisa described.

Moll (1992) and colleagues have argued that the ultimate goal of these innovations "depends on when and how teachers become part of the decision to initiate change" (p. 229). This study describes an evolving commitment of PSTs towards educational changes that place students' own knowledge at the center of mathematical education. Although PSTs' efforts to support their students' mathematical learning in their students' funds of knowledge were evident, it was also clear that in the process of developing the mathematical tasks PSTs' funds of knowledge played an important role too. Most of the PSTs (20/22) were actually able to bridge school mathematics, realistic mathematics applications and students' funds of knowledge. 
At a certain point, PSTs found some kind of familiarity during the design of the mathematical tasks because their prior experiences as students somehow resembled their students' activities, although the content could not exactly be the same. For example, Daniel's familiarity with music, not necessarily the same type of music of his students like, helped him to see potential links between sounds, rhythm and mathematical patterns.

Nevertheless, some PSTs with least familiarity with students' funds of knowledge faced greater challenges trying to establish these links. They designed tasks with less realistic applications and with lower levels of cognitive reasoning (STEIN et al., 2000). Like Aguirre, Zavala \& Katanyoutanant (2012), questions related to these shortcomings should be explored in relation to pedagogical issues. Perhaps, it might be helpful for PSTs' to engage in a more ethnographic approach to understand the diverse community practices and activities that are unfamiliar to them, so they can get better ideas to establish these links.

Mathematics methods courses could help PSTs to develop this type of awareness and also strategies to develop mathematical tasks that are inclusive in terms of their students' funds of knowledge. One way to establish connections with unfamiliar activities perhaps could be through engaging in an Extended Related Activity (see LÓPEZLEIVA, 2014) that could help us to become more familiar with the diverse community activities and mathematize them.

Another way to get to know students better (MOSCHKOVICH, 1999) could be by developing a mutual learning process between PSTs and students they work with. That way PSTs learn about their students through the development of a closer relationship with one student or more. This resembles Moll's household visits and interviews with parents, so that PSTs could learn more about community practices and knowledges.

The goal of Mathematics Teacher Education is to take an ethnomathematical perspective, so PSTs can learn about their students' funds of knowledge. The first step would be to identify a border that needs to be overcome and blur (KEATING, 2006) through 'transformative practice zones' (BRESLER, 2003) of working and the development of closer relationships with students. We need mathematics teaching practices that recognize and challenge spaces of marginalized knowledges of many communities; and strengthen the relationship between students and mathematics (AGUIRRE, INGRAM-MAYFIELD \& MARTIN, 2013).

We need mathematics teachers - and mathematics teacher educators - critical and smart enough to notice and identify borders, but most of all, sensitive and creative enough to make breakthroughs that promote knowledge and relationships among students, teachers and 
mathematics.

Furthermore, PSTs' understanding of funds of knowledge was also crucial in the development of empathy and commitment helping them to integrate students' identities in mathematics teaching. PSTs' understanding of both concepts and their relevance was promoted through a system that transcended the mathematics methods course and reached a system of support provided by the TECLA program through the Literacy courses and the fieldwork seminar. This confirms that an integrated approach in PSTs' preparation provides a rich conceptual, pedagogical and practical context to teaching and learning mathematics.

Acknowledgment: The TECLA (Teacher Education Collaborative in Language Diversity and Arts Integration) project was developed by seven faculty at the University of New Mexico from three programs and two colleges that include, Drs. Rebecca Sanchez, Sylvia Celedon-Pattichis, Carlos LópezLeiva, Nancy Pauly, Leila Flores-Dueñas, Karla Kingsley, Eileen Waldschmidt, and Amy Sweet (Arts Teacher). TECLA is funded partly by a private donor.

\section{References}

AGUIRRE, Julia M. Developing culturally responsive Mathematics teaching. Fall 2012 TODOS Newsletter TODOS - Mathematics For All.

AGUIRRE, Julia M.; TURNER, Erin E.; BARTELL, Tonya Gau; KALINEC-CRAIG, Crystal; FOOTE, Mary Q.; ROTH MCDUFFIE, Amy; DRAKE, Corey. Making Connections in Practice: How Prospective Elementary Teachers Connect to Children's Mathematical Thinking and Community Funds of Knowledge in Mathematics Instruction. Journal of Teacher Education, v. 64, n. 2, p. 178192, 2013.

AGUIRRE, Julia M.; ZAVALA, Maria del Rosario; KATANYOUTANANT, Tiffany. Developing Robust Forms of Pre-Service Teachers' Pedagogical Content Knowledge through Culturally Responsive Mathematics Teaching Analysis. Mathematics Teacher Education and Development, v. 14, n. 2, p. 113-136, 2012.

AGUIRRE, Julia; MAYFIELD-INGRAM, Karen; MARTIN, Danny Bernardo. The impact of identity in K-8 mathematics: Rethinking equity-based practices. Reston: NCTM, 2013.

BISHOP, Allan John. Mathematical enculturation: a cultural perspective on Mathematics Education. Boston: Kluwer, 1988.

BOALER, Jo; GREENO, James G. Identity, agency, and knowing in mathematics worlds. In: BOALER, Jo (Ed.). Multiple perspectives on mathematics teaching and learning. Westport: Ablex, 2000, p. 171-200. 
BRESLER, Liora. Out of the trenches: the joys (and risks) of cross-disciplinary collaborations. Council of Research in Music Education, n. 152, p. 17-39, 2003.

BRESSER, Rusty. Helping English language learners develop computational fluency. Teaching Children Mathematics, v. 9, n. 6, p. 294-300, feb. 2003.

CARPENTER, Thomas P.; FENNEMA, Elizabeth; FRANKE, Megan Loef; LEVI, Linda; EMPSON, Susan B. Children's mathematics: Cognitively Guided Instruction. $2^{\text {nd }}$ ed. Portsmouth: Heinemann, 2014.

CHAPIN, Suzanne H.; O'CONNOR, Catherine; ANDERSON, Nancy Canavan. Classrooms discussions in Math: a teacher's guide for using talk moves to support Common Core and more. 3rd ed. Sausalito: Scholastic, Math Solutions, 2013.

CIVIL, Marta; BERNIER, Emily. Exploring images of parental participation in mathematics education: Challenges and possibilities. Mathematical Thinking and Learning, v. 8, n. 3, p. 309330, nov. 2009.

CIVIL, Marta; BRATTON, Jill; QUINTOS, Beatriz. Parents and Mathematics Education in a Latino Community: redefining parental participation. Multicultural Education, v. 13, n. 2, p. 60-64, 2005.

CIVIL, Marta; QUINTOS, Beatriz. Engaging families in children's mathematical learning: Classroom visits with Latina mothers. New Horizons for Learning Online Journal, v. 12, n. 1, 2006.

D’AMBROSIO, Ubiratan. Matemática, Ensino e Educaçãa: uma proposta global. Temas e Debates, São Paulo, v. 4, n. 3, p. 1-16, 1991.

D'AMBROSIO, Ubiratan; ROSA, Milton. Ethnomathematics and Its Pedagogical Action in Mathematics Education. In: ROSA, Milton; SHIRLEY, Lawrence; GAVARRETE, Maria Elena; ALANGUI, Wilfredo V. (Ed.). Ethnomathematics and its Diverse Approaches for Mathematics Education. Cham, Switzerland: Springer International Publishing, 2017, p. 285-305.

D'AMBROSIO, Ubiratan. Ethnomathematics and its place in the history and pedagogy of mathematics. For The Learning of Mathematics, v. 5, n. 1, p. 44-48, feb. 1985.

DRAKE, Corey; NORTON-MEIER, Lori A. Creating Third Spaces: Integrating Family and Community Resources into Elementary Mathematics Methods. In: 29th Annual Conference of the North American Chapter of the International Group for the Psychology of Mathematics Education. Lake Tahoe, Nevada, 2007.

FALTIS, Christian. Arts-Based Pedagogy for Teaching English Learners. In: OLIVEIRA, Luciana (Ed). Handbook of TESOL in K-12. Hoboken: Wiley, 2019, p. 323-338.

FOSNOT, Catherine T.; DOLK, Maarten. Young mathematicians at work: Constructing number sense, addition, and subtraction. Portsmouth: Heinemann, 2001.

FREUDENTHAL, Hans. Mathematics as an Educational Task. Dordrecht: D. Reidel Publishing Company, 1973.

GALINDO, Rene. Reframing the past in the present: Chicana Teacher Role Identity as a Bridging 
Identity. Education and Urban Society, v. 29, n. 1, 85-102, nov. 1996.

GARRISON, Leslie; MORA, Jill Kerper. Adapting mathematics instruction for English language learners: The language-concept connection. In: ORTIZ-FRANCO, Luis N.; HERNANDEZ, Norma G.; DE LA CRUZ, Yolanda. (Ed.). Changing the faces of mathematics: Perspectives on Latinos. Reston: NCTM, 1999, p. 35-47.

GAY, Geneva. Culturally responsive teaching: theory, research, and practice. 2nd ed. New York: Teachers College Press, 2010.

GONZALEZ, Nora; ANDRADE, R.; CIVIL, Marta; MOLL, Luis C. Bridging funds of distributed knowledge: Creating zones of practices in mathematics. Journal of Education for Students Placed at Risk, v. 6, n. 1 and 2, p. 115-132, 2001.

GRAVEMEIJER, Koeno. Commentary solving word problems: a case of modelling. Learning and Instruction, v. 7, n. 4, p. 389-397, 1997.

HOLSTI, Ole R. Content analysis for the social sciences and humanities. Reading: AddisonWesley, 1969.

KEATING, Ana Louise. From Borderlands and New Mestizas to Nepantlas and Nepantleras: anzalduan theories for social change. Human Architecture: Journal of the Sociology of SelfKnowledge, v. 4, n. 3, p. 5-16, 2006.

KOKKA, Kari. Addressing dilemmas of social justice mathematics through collaboration of students, educators, and researchers. Educational Considerations, v. 43, n. 1, p. 13-21, 2015.

LADSON-BILLINGS, Gloria. But that's just good teaching! A case for culturally relevant pedagogy. Theory into Practice, n. 34, p. 159-165, 1995.

LANGE, Jan de. Using and Applying Mathematics in Education. In: BISHOP, Alan John; CLEMENTS, Ken; KEITEL, Christine; KILPATRICK, Jeremy; LABORDE, Colette. (Ed.). International handbook of Mathematics Education. Kluwer Academic Publisher, 1996, p. 49-97.

LESH, Richard A.; HOOVER, Mark; HOLE, Bonnie; KELLY, Anthony Edward; POST, Thomas. Principles for developing thought-revealing activities for students and teachers. In: KELLY, Anthony Edward; LESH, Richard A. (Ed.). Handbook of research design in Mathematics and Science Education. Mahwah: Lawrence Erlbaum Associates, Inc., 2000, p. 591-646.

LO CICERO, Ana Maria; FUSON, Karen C.; ALLEXSAHT-SNIDER, Martha. Mathematizing children's stories, helping children solve word problems, and supporting parental involvement. In: ORTIZ-FRANCO, Luis N.; HERNANDEZ, Norma G.; DE LA CRUZ, Yolanda. (Ed.). Changing the faces of mathematics: Perspectives on Latinos. Reston: NCTM, 1999, p. 59-70.

LÓPEZLEIVA, Carlos. A. Bilingual Latina/o students model community practices using familiar resources. In: CIVIL Marta; TURNER, Erin E. (Ed.). The Common Core State Standards in Mathematics for English Language Learners, Grades K-8. New York: Teachers College, Columbia University, 2014, p. 95-109. 
LOTAN, Rachel A. Group-worthy tasks. Educational Leadership, v. 60, n. 6, p. 72-75, mar. 2003.

MARSHALL, Julia; DONAHUE, David M. Art-centered learning across the curriculum: Integrating contemporary art in secondary school classroom. New York: Teachers College, 2014.

MOLL, Luis C. Literacy research in community and classrooms: a sociocultural approach. In: BEACH, Richard; GREEN, Judith L.; KAMIL, Michael L.; SHANAHAN, Timothy. (Ed.). Multidisciplinary perspectives on literacy research. National Council of Teachers of English, 1992, p. 211-244.

MOLL, Luis C.; GONZÁLEZ, Nora. Engaging life: a funds of knowledge approach to multicultural education. In BANKS, James A.; BANKS, Cherry A. McGee. (Ed.). Handbook of research on multicultural education. New York: Macmillan, 2004, p. 628-634.

MOLL, Luis. C.; GREENBERG, James B. Creating zones of possibilities: Combining social contexts for instruction. In: MOLL, Luis. C. (Ed.). Vygotsky and Education. New York: Cambridge University Press, 1990, p. 319-348.

MOSCHKOVICH, Judit. A situated and sociocultural perspective on bilingual mathematics learners. Mathematical Thinking and Learning, n. 4, n. 2-3, p. 189-212, 2002.

MOSCHKOVICH, Judit. Principles and guidelines for equitable mathematics teaching practices and materials for English language learners. Journal of Urban Mathematics Education, n. 6, p. 45-57, 2013.

MOSCHKOVICH, Judit. Understanding the needs of Latino students in reform-oriented mathematics classrooms. In: ORTIZ-FRANCO, Luis N.; HERNANDEZ, Norma G.; DE LA CRUZ, Yolanda. (Ed.). Changing the faces of mathematics: Perspectives on Latinos. Reston: NCTM, 1999, p. 5-12.

NCTM. National Council of Teachers of Mathematics. Principles and standards for school mathematics. Reston: NCTM, 2000.

NGACBP. National Governors Association Center for Best Practices. Common Core State Standards for Mathematics. Washington, 2010.

PARIS, Django. Culturally Sustaining Pedagogy: A Needed Change in Stance, Terminology, and Practice. Educational Researcher, v. 41, n. 3, p. 93-97, 2012.

PARRISH, Sherry. Number talks: Helping children mental math and computation strategies, grades K-5. Sausalito: Scholastic, Math Solutions, 2014.

PERKINS, Isabel; FLORES, Alfinio. Mathematical notations and procedures of recent immigrant students. Mathematics Teaching in the Middle School, v. 7, n. 6, p. 346-351, feb. 2002.

RAMIREZ, Nora; CELEDÓN-PATTICHIS, Sylvia. Second language development and implications for math classroom. In: CELEDÓN-PATTICHIS, Sylvia; RAMIREZ, Nora (Ed.). Beyond Good Teaching: Advancing Mathematics Education for ELLs. Reston: NCTM, 2012, p. 19-38.

SIMIC-MULLER, Ksenjia; TURNER, Erin E.; VARLEY, Maura C. Math club: problem posing. 
Teaching Children Mathematics, v.16, n. 4, p. 206-212, nov. 2009.

STEIN, Mary Kay; SMITH, Margareth. S.; HENNINGSEN, Marjorie A.; SILVER, Edward A. Implementing standards-based mathematics instruction: a casebook for professional development. New York: Teachers College Press, 2000.

VAN DE WALLE, John A.; KARP, Karen S.; BAY-WILLIAMS, Jennifer M. Elementary and Middle School Mathematics: Teaching Developmentally (8th ed). Upper Saddle River: Pearson, 2013.

WEBB, David; VAN DER KOOIJ, Henk; GEIST, Monica. R. Design research in the Netherlands: introducing logarithms using Realistic Mathematics Education. Journal of Mathematics Education at Teachers College, v. 2, n. 1, p. 47-52, 2011. 